\title{
Effects of ultraviolet $\mathrm{C}$, controlled atmosphere, and ultrasound pretreatment on free ferulic acid in canned sweet corn kernels
}

\author{
Apinya Chudhangkura ${ }^{1}$ (D) Chowladda Teangpook $^{2} \cdot$ Chomdao Sikkhamondhol $^{1}$. \\ Chansuda Jariyavattanavijit ${ }^{1}$
}

Revised: 19 June 2018 / Accepted: 9 July 2018/Published online: 31 July 2018

(C) Association of Food Scientists \& Technologists (India) 2018

\begin{abstract}
Because canned sweet corn kernel (CSCK) products are subject to high market competitiveness, producing them with a higher content of free ferulic acid (FFA), a functional ingredient, using non-thermal and green technologies may be an alternative solution for Thai exporters. This study aimed to investigate the effects of pre-canning ultraviolet $\mathrm{C}$ (UVC), controlled atmosphere (CA), and ultrasound treatments on the FFA content, texture, and colour of CSCKs. UVC irradiation $(0,1.94$ and $4.01 \mathrm{~kJ} / \mathrm{m}^{2}$ ) was tested in combination with storing corn under $\mathrm{CA}$ at $\% \mathrm{O}_{2}: \% \mathrm{CO}_{2}: \% \mathrm{~N}_{2}$ ratios of $21: 0.03: 78$, $3: 10: 87$, and $3: 15: 82$ before canning. Based on the FFA content, two UVC-CA pretreatments were selected for the ensuing experiment. The effects of the selected UVC-CAs in combination with 0,10 , or $20 \mathrm{~min}$ of $35 \mathrm{kHz}$ ultrasound before canning were measured. The FFA content, moisture, texture, and colour of the CSCKs treated with the nine UVC-CA combinations were not significantly different. Corn irradiated with $1.94 \mathrm{~kJ} / \mathrm{m}^{2} \mathrm{UVC}$ and stored under 3:15:82 $\% \mathrm{O}_{2}: \% \mathrm{CO}_{2}: \% \mathrm{~N}_{2}$ before canning exhibited the highest FFA content, followed by corn treated with no UVC and stored at 3:15:82 \% $\mathrm{O}_{2}: \% \mathrm{CO}_{2}: \% \mathrm{~N}_{2}$. Corn treated with ultrasound combined with the two selected UVC-CA treatments showed no differences in FFA content, moisture, texture, or colour. Corn kernels treated with UVC-
\end{abstract}

Apinya Chudhangkura

ifrayc@ku.ac.th

1 Department of Food Chemistry and Physics, Institute of Food Research and Product Development, Kasetsart University, P.O. Box 1043, Kasetsart, Bangkok 10903, Thailand

2 Department of Processing and Preservation, Institute of Food Research and Product Development, Kasetsart University, P.O. Box 1043, Kasetsart, Bangkok 10903, Thailand
CA-ultrasound had a higher FFA content than untreated kernels. UVC-CA-ultrasound pretreatment showed a trend of increasing CSCK FFA content with no change in physical properties. Thus, UVC-CA-ultrasound pretreatment appears to be an alternative process that might add value to CSCKs by increasing FFA content.

Keywords Ferulic acid - Sweet corn · Ultraviolet C . Controlled atmosphere $\cdot$ Ultrasound

\section{Introduction}

Ferulic acid, or 4-hydroxy-3-methoxycinnamic acid, exerts an antioxidant effect in diseases such as cancer, diabetes, cardiovascular disease, and degenerative neurological conditions. (Zhao and Moghadasian 2008). Srinivasan et al. (2007) reported that ferulic acid has anti-inflammatory, anti-diabetic, anti-aging, anticancer, antiapoptotic, hepatoprotective, neuroprotective, pulmonary protective, hypotensive, anti-atherogenic, and radioprotective effects. Ferulic acid is a phenolic acid that is commonly found in cell walls of Gramineae plants in an ester form (Lozovaya et al. 2000) and is cross-linked with polysaccharides or proteins (Ou and Kwok 2004). Through analyses of corn, wheat, oat, and rice, Adom and Liu (2002) found that corn contained the greatest amount of ferulic acid and that more than $98 \%$ was in a bound form. Moreover, thermal processing and enzyme and alkaline digestion assisted in releasing free ferulic acid (FFA) from plant cell walls. FFA is a good antioxidant scavenger of nitrogen dioxide, superoxide, hydroxyl radicals and free radicals of nitrogen dioxide (Ou and Kwok 2004). Saulnier et al. (2001) reported that maize bran heated at $160{ }^{\circ} \mathrm{C}$ did not contain FFA, whereas FFA was detected upon heating above 
$180{ }^{\circ} \mathrm{C}$. This finding is similar to results reported by Dewanto et al. (2002), who found that thermally processed corn had an increased FFA content and decreased bound ferulic acid content compared to raw corn. In Parmar et al. (2016), reported a reduction in ferulic acid contents in canned kidney beans, filed peas and chickpeas. Parmar et al. (2017) found that 11 varieties of freeze-dried kidney beans showed non-significant differences in ferulic acid. The use of feruloyl esterase to release ferulic acid from cell walls of plants is not practical due to the high cost of enzyme production and the time-consuming nature of bacterial digestion of bound ferulic acid. Mild alkaline digestion with sodium hydroxide at $50-70{ }^{\circ} \mathrm{C}$ is a more rapid alternative (Ghatak and Panchal 2010).

However, emerging techniques for preserving and increasing active substances in food without heating (nonthermal processes), including high-pressure processing, pulsed electric field treatment, ultrasound/sonication, ozone utilization, and ultraviolet radiation of fruits and vegetables, have been increasingly studied. Recently, there have been some reports on the positive and negative effects on the functional ingredients of fruits and vegetables after treatment with ultraviolet C (UVC) at 100-280 nm. UV significantly increases the total phenolic contents and flavonoid content of broccoli (Costa et al. 2006), free phenolic contents of banana (Pongprasert et al. 2009), and ferulic acid contents of roasted peanuts (Sales and Resurreccion 2010). The contents of phenolic compounds in tomato fruits show no difference between samples irradiated without UVC or with $2 \mathrm{~kJ} / \mathrm{m}^{2} \mathrm{UVC}$ or between samples irradiated with 4 or $8 \mathrm{~kJ} / \mathrm{m}^{2}$. However, the contents of the phenolic compounds, such as gallic acid, chlorogenic acid, syringic acid, $p$-coumaric acid, and quercetin, in samples receiving no UVC irradiation are significantly different than those in samples irradiated with $4 \mathrm{~kJ} / \mathrm{m}^{2}$ (Liu et al. 2012). By contrast, UVC decreases phenolic contents in strawberry (Pan et al. 2004). Lemoine et al. (2010) found that hot air with UV reduced yellow colour formation and decreased the loss of chlorophyll in fresh-cut broccoli but increased phenolic contents and antioxidant activity during storage. In the same year, Rodov et al. (2010) reported that flavonol levels increased in peeled onion irradiated with low-intensity $\left(1.2 \mathrm{~kJ} / \mathrm{m}^{2}\right)$ and medium-intensity UV $\left(6.0 \mathrm{~kJ} / \mathrm{m}^{2}\right)$ but that decreases were observed upon exposure to high intensity UV $\left(12 \mathrm{~kJ} / \mathrm{m}^{2}\right)$. Additionally, there are many reports of storage conditions affecting the functional contents of fruits and vegetables. Decreases in polyphenolic content are inhibited in mango stored under $3 \% \mathrm{O}_{2}+10 \% \mathrm{CO}_{2}+87 \% \mathrm{~N}_{2}$ compared to that in mango stored in normal air (Kim et al. 2007). Jaramillo et al. (2007) found that the derivatives of ferulic acid increased in white asparagus stored under aerobic rather than anaerobic conditions. Fresh asparagus stored at $25^{\circ} \mathrm{C}$ for
2 days exhibits a phenolic content two times greater than that of asparagus stored at $4{ }^{\circ} \mathrm{C}$. Total flavonols were found to increase by $58 \%$, and anthocyanin increased by $39 \%$ in sheet-sliced onions kept in the dark at $1-2{ }^{\circ} \mathrm{C}$ for 16 days (Pérez-Gregorio et al. 2010). Htwe et al. (2010) found that storing Homnil rice and Red Hommali rice under atmospheres with 0,5 , and $10 \%$ oxygen maintained the anthocyanin content. By using a combination of UVC and controlled atmosphere (CA) storage, the firmness of shiitake mushrooms irradiated with UVC, stored in a modified atmosphere package for 15 days at $1{ }^{\circ} \mathrm{C}$ with $95 \%$ relative humidity, and then stored at $20{ }^{\circ} \mathrm{C}$ for 3 days was maintained. Increases in flavonoid, ascorbic acid, $\mathrm{H}_{2} \mathrm{O}_{2}$ and superoxide anion contents were observed by Jiang et al. (2010). Ultrasound is a new commercially effective extraction process used in the food industry to increase the yield of extracted components, increase extraction rates, and reduce extraction time (Vilkhu et al. 2008; Chemat and Zill-e-Huma 2011). This technique is defined as a "green and innovative" technology.

Sweet corn is an economic crop of Thailand. Seventyfive percent of the total sweet corn output is processed into canned sweet corn. In 2014, the export volume increased $19 \%$ compared with that in 2013, and the export value increased by $15 \%$ in US dollars (Thai Processors' Association 2015). The corn industry is likely to expand further, as The Office of Industrial Economics (2016) reported that the export value of canned sweet corn in 2016 had increased by $20.1 \%$ from that in 2015 . Demand for canned sweet corn remains high in the EU market, and the production and export demand of sweet corn from Thailand is increasing every year, especially to Asian countries, including Japan, Taiwan, and Korea. However, competitiveness in the global market tends to increase. Thai exporters have faced problems such as anti-dumping measures, increased tax rates, and baht appreciation. To enhance the market competitiveness of canned sweet corn kernel products, producing these products with greater contents of health-beneficial ingredients, such as FFA, may be an alternative strategy. Because there is no research on the use of UVC irradiation, CA conditions, and ultrasound waves for pretreatment in sweet corn kernel canning, this study aimed to investigate their effects on the FFA content, texture, and colour of canned sweet corn kernels. The results provide new knowledge that may help the sweet corn industry to add value to their products via these nonthermal and green technologies. 


\section{Materials and methods}

\section{Fresh sweet corn}

The fresh sweet corn (Zea mays var. saccharata) cultivar Insee 2, harvested at 68-70 days after planting, was purchased from the National Corn and Sorghum Research Center, Pak Chong District, Nakhon Ratchasima Province and transported in a foam box to the Institute of Food Research and Product Development, Kasetsart University, Bangkok within $24 \mathrm{~h}$. The fresh sweet corn was stored in a refrigerator at $6^{\circ} \mathrm{C}$ for $4 \mathrm{~h}$ upon arrival.

\section{Effects of ultraviolet $C$ and controlled atmospheric conditions}

\section{Sweet corn preparation and treatment}

After removing the peel and silk, the sweet corn was radiated with a UVC lamp (Sylvania G $40 \mathrm{~W}$, Japan) at intensities of $0,1.94$ and $4.01 \mathrm{~kJ} / \mathrm{m}^{2}$ (coded $\mathrm{V} 1, \mathrm{~V} 2$, and $\mathrm{V} 3$ ) for $6 \mathrm{~min}$ and was then stored under CA conditions with \%oxygen:\%carbon dioxide:\%nitrogen ratios of 21:0.03:78 (normal air), 3:10:87, and 3:15:82 (coded C1, $\mathrm{C} 2$, and $\mathrm{C} 3$, respectively) at $6{ }^{\circ} \mathrm{C}$ for $20 \mathrm{~h}$ before canning. The nine pretreatments were as follows: $0 \mathrm{~kJ} / \mathrm{m}^{2}$ $\mathrm{UVC}+$ normal air (V1C1), $0 \mathrm{~kJ} / \mathrm{m}^{2} \mathrm{UVC}+3 \% \mathrm{O}_{2}: 10 \%-$ $\mathrm{CO}_{2}: 87 \% \mathrm{~N}_{2} \quad$ (V1C2), $\quad 0 \mathrm{~kJ} / \mathrm{m}^{2} \quad \mathrm{UVC}+3 \% \mathrm{O}_{2}: 15 \%-$ $\mathrm{CO}_{2}: 82 \% \mathrm{~N}_{2} \quad(\mathrm{~V} 1 \mathrm{C} 3), \quad 1.94 \mathrm{~kJ} / \mathrm{m}^{2} \quad \mathrm{UVC}+$ normal air (V2C1), $\quad 1.94 \mathrm{~kJ} / \mathrm{m}^{2} \quad \mathrm{UVC}+3 \% \mathrm{O}_{2}: 10 \% \mathrm{CO}_{2}: 87 \% \mathrm{~N}_{2}$ (V2C2), $\quad 1.94 \mathrm{~kJ} / \mathrm{m}^{2} \quad \mathrm{UVC}+3 \% \mathrm{O}_{2}: 15 \% \mathrm{CO}_{2}: 82 \% \mathrm{~N}_{2}$ (V2C3), $4.01 \mathrm{~kJ} / \mathrm{m}^{2} \mathrm{UVC}+$ normal air (V3C1), $4.01 \mathrm{~kJ} /$ $\mathrm{m}^{2} \mathrm{UVC}+3 \% \mathrm{O}_{2}: 10 \% \mathrm{CO}_{2}: 87 \% \mathrm{~N}_{2}(\mathrm{~V} 3 \mathrm{C} 2)$, and $4.01 \mathrm{~kJ} /$ $\mathrm{m}^{2} \mathrm{UVC}+3 \% \mathrm{O}_{2}: 15 \% \mathrm{CO}_{2}: 82 \% \mathrm{~N}_{2}(\mathrm{~V} 3 \mathrm{C} 3)$.

\section{Canning}

After separating the sweet corn kernels from the cob, $110 \mathrm{~g}$ of sweet corn kernels was added to $307 \times 111$ cans, followed by the addition of $60 \mathrm{~g}$ of drinking water, and the cans were then sterilized at $121{ }^{\circ} \mathrm{C}$ for $12 \mathrm{~min}$. This sterilization time was selected based on a preliminary test to check that no Clostridium botulinum was found in the cans of sweet corn kernels.

\section{Analysis of canned sweet corn qualities}

1 month after canning, three cans of sweet corn kernels from each treatment were mixed together and analysed as follows.
Ferulic acid analysis (modified from Buranov and Mazza 2009) A $5 \mathrm{~g}$ of canned sweet corn kernels was blended with $30 \mathrm{ml}$ of $0.5 \mathrm{M}$ sodium hydroxide using an UltraTurrax $^{\circledR}$ T25 basic homogenizer with a S25 N probe $\left(\right.$ IKA $^{\circledR}$-Werke, Germany) at a speed of $6500 \mathrm{rpm}$ for $1 \mathrm{~min}$. The mixture was then heated in a $50{ }^{\circ} \mathrm{C}$ water bath (Heto SBD 50, Denmark) with shaking stroke of 170 for $4 \mathrm{~h}$. After the mixture cooled, it was neutralized with concentrated hydrochloric acid (Merck, Germany), and had $90 \mathrm{ml}$ of $95 \%$ ethanol was added to precipitate hemicelluloses and glucomannan. The mixture was next centrifuged at $4500 \mathrm{rpm}$ for $5 \mathrm{~min}$ with a 1617 rotor (Universal 32, Hettich, Germany). The supernatant was evaporated in a BÜchi Syncore ${ }^{\circledR}$ Analyst (Switzerland) at $45^{\circ} \mathrm{C}$ until approximately $1 \mathrm{ml}$ of liquid remained, following by adjustment with AR-grade pure ethanol (Merck, Germany) in a $10 \mathrm{ml}$ volumetric flask. The sample solution was subsequently filtered through a nylon membrane filter, $0.45 \mu \mathrm{m}$ pore size. FFA content was analyzed by HPLC (Agilent 1100, USA) with a UV detector at $254 \mathrm{~nm}$ and an $\mathrm{ACE}^{\circledR} 5 \mathrm{C} 18$ column (Scotland; $5 \mu \mathrm{m}$ and $150 \times 4.6 \mathrm{~mm}$ ) at room temperature using HPLC-grade acetonitrile (J.T. Baker, USA) and $0.1 \%$ formic acid (Merck, Germany) at 20:80 (v/v), filtered through a $0.2 \mu \mathrm{m}$ nylon membrane filter as a mobile phase in an isocratic system with a $1 \mathrm{ml} /$ min flow rate. One-microliter samples were injected. FFA was calculated from a standard curve of $99 \%$ standard ferulic acid (Sigma-Aldrich, USA).

Moisture (AOAC 2005) Two-gram canned sweet corn kernels were determined for moisture content using hot air oven at $105^{\circ} \mathrm{C}$ according to AOAC method Hardness (modified from Fan and Sokorai 2007) Five-gram samples of canned sweet corn kernels were measured for hardness using a Model TA.XT2i Texture Analyzer (Stable Micro System, UK) with a mini Kramer shear 5-blade probe at an operating speed of $2 \mathrm{~mm} / \mathrm{sec}$ and an operating distance of $20 \mathrm{~mm}$.

Colour A windowed grain holder was filled with canned sweet corn kernels. Their colour was measured using a Spectraflash $^{\circledR}$ SF600 ${ }^{\circledR}$ Plus instrument (Data Color International, USA) with a $30-\mathrm{mm}$ aperture and Commission Internationale de l'Elcairage (CIE) standard illuminant D65/10.

Two pretreatments yielding large amounts of FFA were selected for the next experiment. 
Effects of the selected ultraviolet $\mathrm{C}-\mathrm{CA}$ conditions and ultrasound

\section{Preparation of sweet corn kernels}

After the sweet corn was treated under the selected UVCCA conditions, corn kernels were separated, and glass beakers were filled with the kernels. Drinking water was then added to cover the kernels. Next, the beakers were placed in a Transsonic 570/H system (Elma ${ }^{\circledR}$, Germany) generating low-frequency ultrasound waves $(35 \mathrm{kHz})$ for 0 , 10, or $20 \mathrm{~min}$ (code S1, S2, and S3). The six pretreatments were designated $\mathrm{VxCxS} 1, \mathrm{VxCxS} 2, \mathrm{VxCxS} 3, \mathrm{VyCyS} 1$, VyCyS2, and VyCyS3.

\section{Canning}

Samples of $110 \mathrm{~g}$ of sweet corn kernels with $60 \mathrm{~g}$ of water from the treated beakers were added to $307 \times 111$ cans. The canned sweet corn was then sterilized at $121{ }^{\circ} \mathrm{C}$ for $12 \mathrm{~min}$

\section{Analysis of canned sweet corn qualities}

The same methods described in "Effects of the selected ultraviolet C-CA conditions and ultrasound" section were used.

\section{Statistical analysis}

The experimental design for the UVC-CA experiment was a $3 \times 3$ in completely randomized design (CRD), while that for the UVC-CA ultrasound experiment was a 2x3 in CRD. Both experiments were conducted with two replications. ANOVA and least significant difference (LSD) tests were used to evaluate the differences between mean values, with significance set at the 5\% level $(p<0.05)$ using SPSS 16 software (SPSS Inc., USA).

\section{Results and discussion}

\section{Effects of UVC-CA conditions}

Before canning, sweet corn was treated with UVC at intensities of $0,1.94$, and $4.01 \mathrm{~kJ} / \mathrm{m}^{2}$ (coded $\mathrm{V} 1, \mathrm{~V} 2$, and V3) and stored under CA conditions with \%oxygen:\%carbon dioxide:\%nitrogen ratios of 21:0.03:78 (normal air), 3:10:87, and 3:15:82 (coded $\mathrm{C} 1, \mathrm{C} 2$, and $\mathrm{C} 3$, respectively) at $6{ }^{\circ} \mathrm{C}$ for $20 \mathrm{~h}$. The FFA contents of all canned sweet corn kernel samples were not significantly different $(p>0.05)$. Corn kernel samples could be separated into three groups according to the atmospheric conditions: group 1 (V1C1, V2C1, V3C1), group 2 (V1C2, V2C2, $\mathrm{V} 3 \mathrm{C} 2$ ), and group 3 (V1C3, V2C3, V3C3). Among the samples from each group, FFA contents tended to be stable when the UVC intensity increased (Fig. 1). The three levels of UVC $\left(0,1.94\right.$, and $\left.4.01 \mathrm{~kJ} / \mathrm{m}^{2}\right)$ did not influence FFA levels of sweet corn kernels. This finding was similar to those of Liu et al. (2012), who found that the levels of the phenolic compounds catechin and caffeic acid were not significantly different in tomatoes treated with UVC at $0,2,4,8$, or $16 \mathrm{~kJ} / \mathrm{m}^{2}$. Zainol et al. (2016) also reported that UV light did not affect on ferulic acid extraction from banana stem waste when UV was used for pretreatment. By contrast, strawberries showed decreased anthocyanin and phenolic contents after being exposed to UVC at $1-4.1 \mathrm{~kJ} / \mathrm{m}^{2}$ (Pan et al. 2004). FFA levels were obviously higher in the group 3 samples than in the groups 1 and 2 samples. V2C 3 showed the highest FFA content of $217.22 \pm 1.26 \mathrm{mg} / 100 \mathrm{~g}$ (dry basis), followed by $205.95 \pm 24.13$ and $191.28 \pm 44.36 \mathrm{mg}$ FFA/100 g (dry basis) in V1C3 and V3C3, respectively. The kernels treated with all UVC intensities in combination with a normal air or 3:10:87 $\% \mathrm{O}_{2}: \% \mathrm{CO}_{2}: \% \mathrm{~N}_{2}$ atmosphere (groups 1 and 2) exhibited low FFA contents ranging from 158.08 to $169.98 \mathrm{mg} / 100 \mathrm{~g}$ (dry basis). This finding was similar to a study in which total polyphenolics increased in cherimoya fruit exposed to a 20:20:60 $\% \mathrm{O}_{2}: \% \mathrm{CO}_{2}: \% \mathrm{~N}_{2}$ atmosphere but remained unchanged under normal air (Asiss et al. 2001). No difference was observed between the total phenolic contents of sweet corn kernels stored under a normal air or $5 \% \mathrm{O}_{2}+10 \% \mathrm{CO}_{2}$ atmosphere (Riad et al. 2003).

The canned sweet corn kernels from all treatments exhibited 80.02-80.28\% moisture content (data not shown), 12.94-15.20 kg hardness, 62.45-64.78 lightness ( $\mathrm{L}^{*}$ value), 5.16-7.39 redness (a* value), and 36.51-47.98

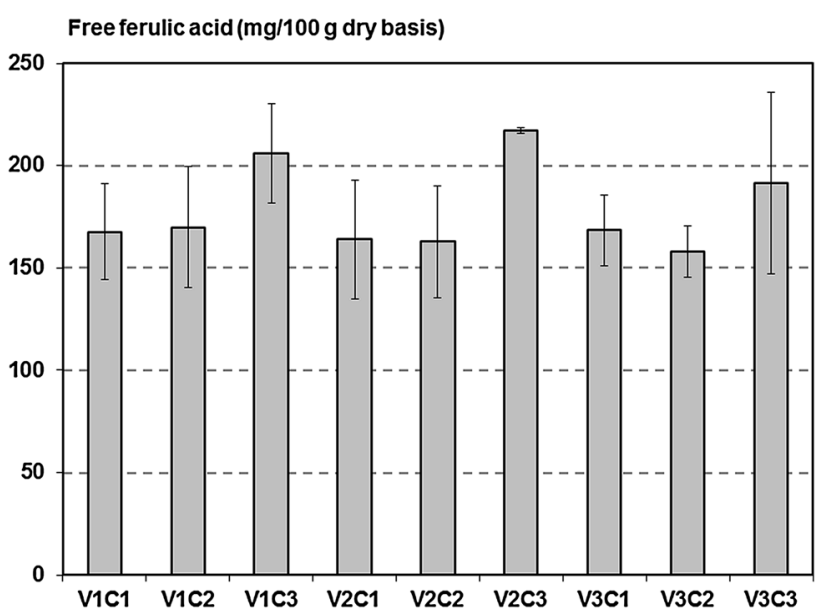

Fig. 1 FFA content of canned sweet corn kernels pretreated with UVC-CA before canning (V1, no UVC; V2, $1.94 \mathrm{~kJ} / \mathrm{m}^{2} \mathrm{UVC}$; V3, $4.01 \mathrm{~kJ} / \mathrm{m}^{2} \mathrm{UVC}$; $\mathrm{C} 1$, normal air; $\mathrm{C} 2,3 \% \mathrm{O}_{2}: 10 \% \mathrm{CO}_{2}: 87 \% \mathrm{~N}_{2}$; and $\mathrm{C} 3,3 \% \mathrm{O}_{2}: 15 \% \mathrm{CO}_{2}: 82 \% \mathrm{~N}_{2}$ ) 
yellowness $\left(b^{*}\right.$ value), none of which were significantly different between treatment $(p>0.05)$ (Figs. 2, 3). Hardness tended to be stable, ranging from 12.94 to $15.20 \mathrm{~kg}$, which is similar to the unchanged firmness observed in shiitake mushrooms irradiated with $4 \mathrm{~kJ} / \mathrm{m}^{2} \mathrm{UVC}$ and then stored in a modified atmosphere-package for 15 days at $1{ }^{\circ} \mathrm{C}$ (Jiang et al. 2010). Corn kernel colour also did not significantly differ. This agreed with results of Raid et al. (2003), who reported that CA could prevent browning in cooked sweet corn kernels. By contrast, calyx browning has been observed in strawberries irradiated with UVC at $1-4.1 \mathrm{~kJ} / \mathrm{m}^{2}$ (Pan et al. 2004), and button mushrooms exposed to UVC show immediately darkening compared to non-irradiated samples ( $\mathrm{Lu}$ et al. 2016).

Due to resulting in the highest FFA contents, the treatments of no UVC in combination with $3: 15: 82$ $\% \mathrm{O}_{2}: \% \mathrm{CO}_{2}: \% \mathrm{~N}_{2}$ atmosphere storage $(\mathrm{V} 1 \mathrm{C} 3)$ and $1.94 \mathrm{~kJ} /$ $\mathrm{m}^{2}$ UVC in combination with $3: 15: 82$ (V2C3) were selected as the two pretreatments for the next experiment.

\section{Effects of selected UVC-CA conditions and ultrasound}

Post-treatment V1C3 and V2C3 corn kernels were sonicated with low-frequency ultrasound waves $(35 \mathrm{kHz})$ for 0 , 10 , or 20 min (coded S1, S2, and S3) before canning, yielding six pretreatments: V1C3S1, V1C3S2, V1C3S3, $\mathrm{V} 2 \mathrm{C} 3 \mathrm{~S} 1, \mathrm{~V} 2 \mathrm{C} 3 \mathrm{~S} 2$, and V2C3S3. The FFA contents of all canned sweet corn kernels did not differ significantly $(p>0.05)$ (Fig. 4). However, the V1C3S3 sample showed the highest FFA content of $287.99 \pm 48.66 \mathrm{mg} / 100 \mathrm{~g}$ (dry basis), followed by V1C3S2, V2C3S3, and V2C3S2, which contained $\quad 277.07 \pm 23.86, \quad 249.06 \pm 62.91, \quad$ and $244.87 \pm 10.91 \mathrm{mg}$ FFA/100 g (dry basis), respectively.

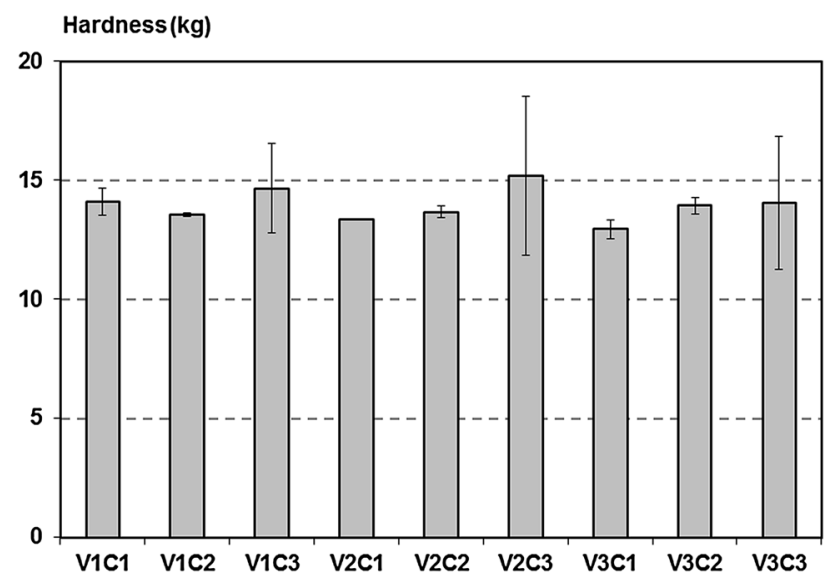

Fig. 2 Hardness of canned sweet corn kernels pretreated with UVCCA before canning (V1, no UVC; V2, $1.94 \mathrm{~kJ} / \mathrm{m}^{2} \mathrm{UVC}$; V3, $4.01 \mathrm{~kJ} /$ $\mathrm{m}^{2}$ UVC; $\mathrm{C} 1$, normal air; $\mathrm{C} 2,3 \% \mathrm{O}_{2}: 10 \% \mathrm{CO}_{2}: 87 \% \mathrm{~N}_{2}$; and $\mathrm{C} 3$, $3 \% \mathrm{O}_{2}: 15 \% \mathrm{CO}_{2}: 82 \% \mathrm{~N}_{2}$ )

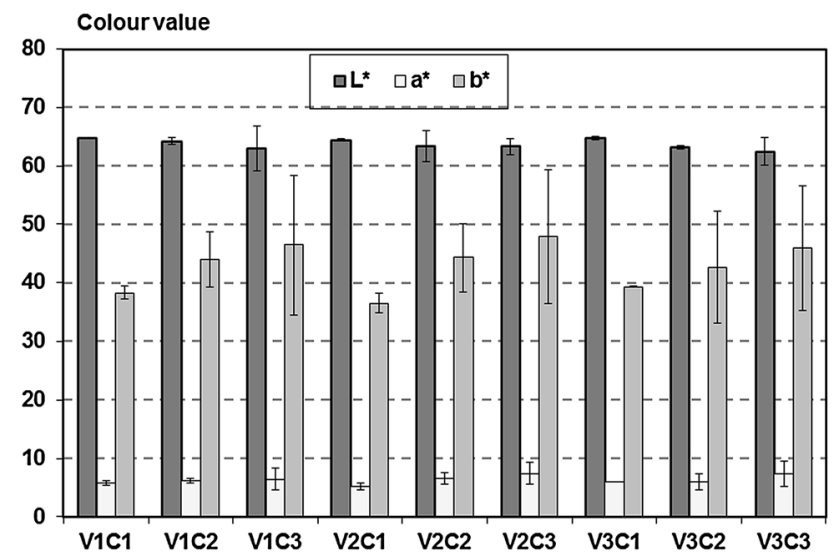

Fig. 3 Colour value of canned sweet corn kernels pretreated with UVC-CA before canning (V1, no UVC; V2, $1.94 \mathrm{~kJ} / \mathrm{m}^{2} \mathrm{UVC}$; V3, $4.01 \mathrm{~kJ} / \mathrm{m}^{2}$ UVC; $\mathrm{C} 1$, normal air; $\mathrm{C} 2,3 \% \mathrm{O}_{2}: 10 \% \mathrm{CO}_{2}: 87 \% \mathrm{~N}_{2}$; and $\mathrm{C} 3,3 \% \mathrm{O}_{2}: 15 \% \mathrm{CO}_{2}: 82 \% \mathrm{~N}_{2}$ )

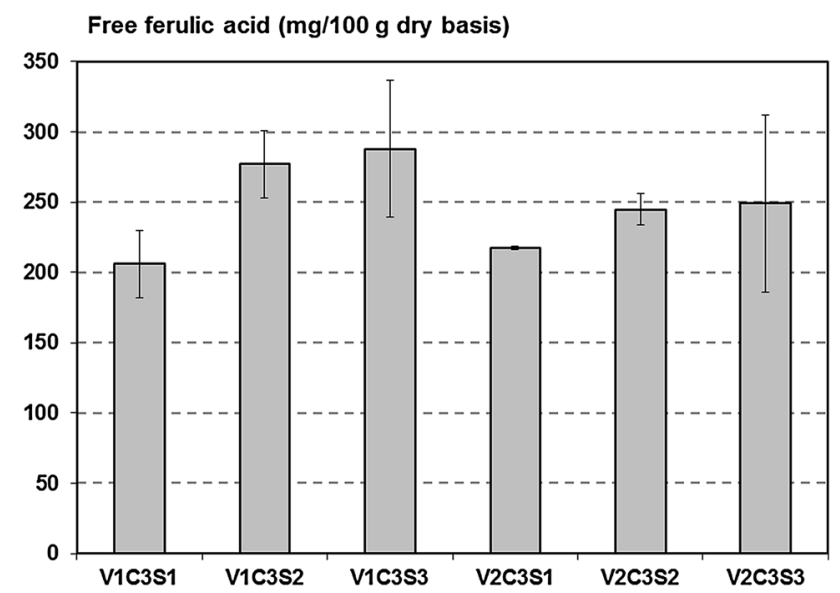

Fig. 4 FFA content of canned sweet corn kernels pretreated with UVC-CA-ultrasound before canning (V1, no UVC; V2, $1.94 \mathrm{~kJ} / \mathrm{m}^{2}$ UVC; C3, $3 \% \mathrm{O}_{2}: 15 \% \mathrm{CO}_{2}: 82 \% \mathrm{~N}_{2} ; \mathrm{S} 1$, no ultrasound; S2, $10 \mathrm{~min}$ ultrasound; $\mathrm{S} 3,20 \mathrm{~min}$ ultrasound)

The FFA contents of the canned sweet corn kernels were positively correlated with the ultrasound pretreatment time. This finding agreed with those of Tao and Sun (2015), who reported that ultrasound extraction efficiency is time-dependent; longer extraction times were correlated with higher extraction yields. Ultrasound caused an increase in FFA due to surface deterioration of the corn kernels. Awad et al. (2012) reported that surface erosion and mass transfer increased by ultrasound at frequencies above $20 \mathrm{kHz}$, resulting in shorter extraction times and higher yields. In addition, cell structure damaged possibly by solvent streams from collapsing bubbles combined with mechanical vibration, has been found in cabbage leaves treated with ultrasound at $37 \mathrm{kHz}$ (Pongmalai et al. 2013).

The moisture contents and hardness of all treated kernels were not significantly different $(p>0.05)$, ranging from 


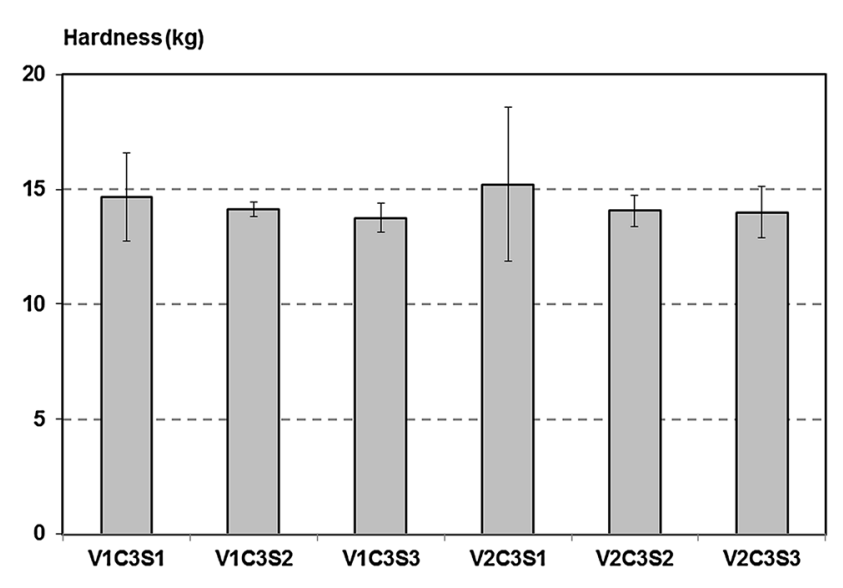

Fig. 5 Hardness of canned sweet corn kernels pretreated with UVCCA-ultrasound before canning (V1, no UVC; V2, $1.94 \mathrm{~kJ} / \mathrm{m}^{2} \mathrm{UVC}$; $\mathrm{C} 3,3 \% \mathrm{O}_{2}: 15 \% \mathrm{CO}_{2}: 82 \% \mathrm{~N}_{2} ; \mathrm{S} 1$, no ultrasound; $\mathrm{S} 2,10 \mathrm{~min}$ ultrasound; S3, 20 min ultrasound)

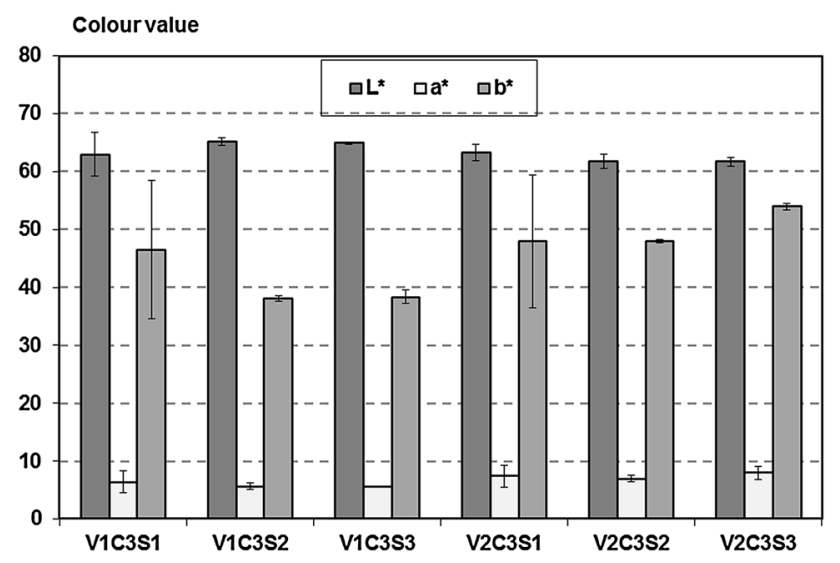

Fig. 6 Colour value of canned sweet corn kernels pretreated with UVC-CA-ultrasound before canning (V1, no UVC; V2, $1.94 \mathrm{~kJ} / \mathrm{m}^{2}$ UVC; $\mathrm{C} 3,3 \% \mathrm{O}_{2}: 15 \% \mathrm{CO}_{2}: 82 \% \mathrm{~N}_{2} ; \mathrm{S} 1$, no ultrasound; S2, $10 \mathrm{~min}$ ultrasound; S3, 20 min ultrasound)

80.04 to $81.96 \%$ (data not shown) and $13.76-15.20 \mathrm{~kg}$, respectively (Fig. 5). The colour of all treated corn kernels was not significantly different $(p>0.05)$, with $\mathrm{L}^{*}$, a, and $\mathrm{b}^{*}$ ranging from 61.69-65.16, 5.62-7.99, and 38.21-53.94, respectively (Fig. 6). $10 \mathrm{~min}$ of ultrasound seemed to decrease $\mathrm{b}^{*}$ in $\mathrm{V} 1 \mathrm{C} 3 \mathrm{~S} 1$ and $\mathrm{V} 2 \mathrm{C} 3 \mathrm{~S} 1$, while $20 \mathrm{~min}$ of ultrasound seemed to maintain $\mathrm{b}^{*}$ in V1C3S2 and increase $\mathrm{b}^{*}$ in V2C3S2. An ultrasound frequency of $35 \mathrm{kHz}$ may have affected the colour of the canned sweet corn kernels. Awad et al. (2012) reported that ultrasound from 20 to $500 \mathrm{kHz}$ alters the properties of food.

\section{Conclusion}

The combination of UVC irradiation and CA storage prior to sweet corn kernel canning did not significantly increase FFA. A CA with 3:15:82 $\% \mathrm{O}_{2}: \% \mathrm{CO}_{2}: \% \mathrm{~N}_{2}$ tended to affect the FFA content, whereas the three tested levels of UVC had no effect. Treating sweet corn with $35 \mathrm{kHz}$ ultrasound before canning tended to increase the FFA content of canned sweet corn kernels compared to that in untreated samples. The texture and colour of the canned sweet corn kernels showed no clear effects of any pretreatment. Therefore, a UVC-CA ultrasound pretreatment could be a potential strategy for adding value to canned sweet corn kernels in terms of FFA content. More experiments are needed to confirm the potential of these pretreatments to increase FFA levels. By evaluating the effect of each pretreatment separately and strictly controlling the maturity and harvesting season of sweet corn, significant results may be determined. Ultrasound pretreatment may be a potentially non-thermal, green technology for increasing the FFA contents of other thermally processed corn kernel products.

Acknowledgements Financial support for this research was provided by the Kasetsart University Research and Development Institute (KURDI), Thailand.

\section{Compliance with ethical standards}

Conflict of interest None.

\section{References}

Adom KK, Liu RH (2002) Antioxidant activity of grains. J Agric Food Chem 50(21):6182-6187. https://doi.org/10.1021/ jf0205099

AOAC (2005) Official methods of analysis of AOAC International, 18th edn. AOAC International, Gaithersburg

Assis JS, Maldonado R, Muñoz T, Escribano MI, Merodio C (2001) Effect of high carbon dioxide concentration on PAL activity and phenolic contents in ripening cherimoya fruit. Postharvest Biol Technol 23:33-39. https://doi.org/10.1016/S09255214(01)00100-4

Awad TS, Moharram HA, Shaltout OE, Asker D, Youssef MM (2012) Applications of ultrasound in analysis, processing and quality control of food: a review. Food Res Int 48:410-427. https://doi. org/10.1016/j.foodres.2012.05.004

Buranov AU, Mazza G (2009) Extraction and purification of ferulic acid from flax shives, wheat and corn bran by alkaline hydrolysis and pressurised solvents. Food Chem 115:1542-1548. https:// doi.org/10.1016/j.foodchem.2009.01.059

Chemat F, Zill-e-Huma Khan MK (2011) Applications of ultrasound in food technology: processing, preservation and extraction. Ultrason Sonochem 18:813-835. https://doi.org/10.1016/j.ult sonch.2010.11.023

Costa L, Vicente AR, Civello PM, Chaves AR, Martínez GA (2006) UV-C treatment delays postharvest senescence in broccoli florets. Postharvest Biol Technol 39(2):204-210. https://doi. org/10.1016/j.postharvbio.2005.10.012

Dewanto V, Wu X, Liu RH (2002) Processed sweet corn has higher antioxidant activity. J Agric Food Chem 50:4959-4964. https:// doi.org/10.1021/jf0255937

Fan X, Sokorai KJB (2007) Effects of ionizing radiation on sensorial, chemical, and microbiological quality of frozen corn and peas. 
J Food Prot 70(8):1901-1908. https://doi.org/10.4315/0362028X-70.8.1901

Ghatak SB, Panchal SJ (2010) Ferulic acid - an insight into its current research and future prospects. Trends Food Sci Technol (In Press). https://doi.org/10.1016/j.tifs.2010.11.004. Accessed 2 October 2017

Htwe NN, Srilaong V, Tanprasert K, Photchanachai S, Kanlayanarat S, Uthairatanakij A (2010) Low oxygen concentrations affecting antioxidant activity and bioactive compounds in coloured rice. As J Food Ag-Ind 3(2):269-281. http://www.thaiscience.info/ journals/Article/AFAI/10850256.pdf. Accessed 16 September 2013

Jaramillo S, Rodríguez R, Jiménez A, Guillén R, Fernández-Bolaños J, Heredia A (2007) Effects of storage conditions on the accumulation of ferulic acid derivatives in white asparagus cell walls. J Sci Food Agric 87:286-296. https://doi.org/10.1002/jsfa. 2718

Jiang T, Jahangir MM, Jiang Z, Lu X, Ying T (2010) Influence of UV$\mathrm{C}$ treatment on antioxidant capacity, antioxidant enzyme activity and texture of postharvest shiitake (Lentinus edodes) mushrooms during storage. Postharvest Biol Technol 56:209-215. https:// doi.org/10.1016/j.postharvbio.2010.01.011

Kim Y, Bretch JK, Talcott ST (2007) Antioxidant phytochemical and fruit quality changes in mango (Mangifera indica L.) following hot water immersion and controlled atmosphere storage. Food Chem 105:1327-1334. https://doi.org/10.1016/j.foodchem.2007. 03.050

Lemoine ML, Civello PM, Chaves AR, Martinez GA (2010) Influence of combinated hot air and UV-C treatment on quality parameters of fresh-cut broccoli florets at $0{ }^{\circ} \mathrm{C}$. Intl $\mathrm{J}$ Food Sci Tech 45:1212-1218. https://doi.org/10.1111/j.1365-2621.2010.02269. $\mathrm{x}$

Liu C, Cai L, Lu X, Han X, Ying T (2012) Effect of postharvest UV$\mathrm{C}$ irradiation on phenolic compound content and antioxidant activity of tomato fruit during storage. $\mathrm{J}$ Integr Agric 11(1):159-165. https://doi.org/10.1016/S1671-2927(12)60794-9

Lozovaya VV, Gorshkova TA, Rumyantseva NI, Ulanov AV, Valieva AI, Yablokova EV, Chuansheng M, Widholm JM (2000) Cell wall-bound phenolics in cells of maize (Zea mays, Gramineae) and buckwheat (Fagopyrum tataricum, Polygonaceae) with different plant regeneration abilities. Plant Sci 152:79-85. https://doi.org/10.1016/S0168-9452(99)00225-3

Lu Y, Zhang J, Wang X, Lin Q, Liu W, Xie X, Wang Z, Guan W (2016) Effects of UV-C irradiation on the physiological and antioxidant responses of button mushrooms (Agaricus bisporus) during storage. InterJ Food Sci Technol 51:1502-1508. https:// doi.org/10.1111/ijfs. 13100

Ou S, Kwok KC (2004) Ferulic acid: pharmaceutical functions, preparation and applications in foods. J Sci Food Agric 84(11):1261-1269. https://doi.org/10.1002/jsfa.1873

Pan J, Vicente AR, Martínez GA, Chaves AR, Civello PM (2004) Combined use of UV-C irradiation and heat treatment to improve postharvest life of strawberry fruit. J Sci Food Agric 84(14):1831-1838. https://doi.org/10.1002/jsfa.1894

Parmar N, Singh N, Kaur A, Virdi AS, Thakur S (2016) Effect of canning on color, protein and phenolic profile of grains from kidney bean, field pea and chickpea. J Food Res 89:526-532. https://doi.org/10.1016/j.foodres.2016.07.022

Parmar N, Singh N, Kaur A, Thakur S (2017) Comparison of color, anti-nutritional factors, minerals, phenolic profile and protein digestibility between hard-to-cook and easy-to-cook grains from different kidney bean (Phaseolus vulgaris) accessions. J Food
Sci Technol 54(4):1023-1034. https://doi.org/10.1007/s13197017-2538-3

Pérez-Gregorio RM, García-Falcón MS, Simal-Gándara J, Rodrigues AS, Almeida DPF (2010) Identification and quantification of flavonoids in traditional cultivars of red and white onions at harvest. J Food Compos Anal 23(6):592-598. https://doi.org/10. 1016/j.jfca.2009.08.013

Pongmalai P, Devahastin S, Chiewchan N, Soponronnarit S (2013) Effect of ultrasonic pretreatment on extractability of glucosinolates from cabbage outer leaves. In: The 14th TSAE national conference and the 6th TSAE international conference: TSAE 2013, 119-122. http://www.repository.rmutt.ac.th/xmlui/bit stream/handle/123456789/1732/FE-08\%20p119-122.pdf?se quence $=1$. Accessed 26 March 2017

Pongprasert N, Sekosawa Y, Sugaya S, Gemma H (2009) A possible role and mode of action of UV-C illumination on inducing chilling stress tolerance in banana peel. Acta Hortic 837:313-320. https://doi.org/10.17660/ActaHortic.2009.837.42

Riad GS, Brecht JK, Talcott ST (2003) Browning of fresh-cut sweet corn kernels after cooking is prevented by controlled atmosphere storage. Acta Hortic 628:387-394. https://doi.org/10.17660/ ActaHortic.2003.628.48

Rodov V, Tietel Z, Vinokur Y, Horev B, Eshel D (2010) Ultraviolet light stimulates flavonol accumulation in peeled onions and controls microorganisms on their surface. J Agri Food Chem 58(16):9071-9076. https://doi.org/10.1021/jf1016016

Sales JM, Resurreccion AVA (2010) Phenolic profile, antioxidants, and sensory acceptance of bioactive-enhanced peanuts using ultrasound and UV. Food Chem 122:795-803. https://doi.org/10. 1016/j.foodchem.2010.03.058

Saulnier L, Marot C, Elgorriaga M, Bonnin E, Thibault JF (2001) Thermal and enzymatic treatments for release of free ferulic acid from maize bran. Carbohydr Polym 45:269-275. https://doi.org/ 10.1016/S0144-8617(00)00259-9

Srinivasan M, Sudheer AR, Venon VP (2007) Ferulic acid: therapeutic potential through its antioxidant property. J Clin Biochem Nutr 40(2):92-100. https://doi.org/10.3164/jcbn.40.92

Tao Y, Sun D (2015) Enhancement of food processes by ultrasound: a review. Crit Rev Food Sci Nutr 55:570-594. https://doi.org/10. 1080/10408398.2012.667849

Thai Food Processors'Association (2015) NEWS\&Situations (in Thai). TFPA Newsletter, 3(5):1-2. http://thaifood.org/wp-con tent/uploads/2015/02/Newsletter_vol-3-Issue5.pdf. Accessed 22 March 2017

The Office of Industrial Economics (2016) Industrial Economic Status Report March 2016. p 6 http://www.oie.go.th/sites/default/files/ attachments/monthly_report_en/en_newbriefmar2016.pdf. Accessed 22 March 2017

Vilkhu K, Mawson R, Simons L, Bates D (2008) Applications and opportunities for ultrasound assisted extraction in the food industry-a review. Innov Food Sci Emerg Technol 9:161-169. https://doi.org/10.1016/j.ifset.2007.04.014

Zainol N, Masngut N, Ismail SN (2016) Effect of pre-treatment processes to ferulic acid extraction from banana stem waste. In: International conference on agricultural and food engineering (Cafei2016), 23-25 August, 10(6):332-337. cafei.upm.edu.my/download.php?filename $=/$ TechnicalPapers/ CAFEi2016-198.pdf. Accessed 22 March 2017

Zhao Z, Moghadasian MH (2008) Chemistry, natural sources, dietary intake and pharmacokinetic properties of ferulic acid: a review. Food Chem 109:691-702. https://doi.org/10.1016/j.foodchem. 2008.02.039 